\title{
Medical treatment of renal cancer: new horizons
}

\author{
Basma Greef ${ }^{\star}, 1$ and Tim Eisen ${ }^{2}$ \\ ${ }^{1}$ Department of Oncology, Cambridge University Hospitals NHS Foundation Trust, Addenbrooke's Hospital, Box 193, Hills Road, \\ Cambridge CB2 0QQ, UK and ${ }^{2}$ Department of Oncology, University of Cambridge, Cambridge Biomedical Campus, Cambridge \\ CB2 0QQ, UK
}

Renal cell carcinoma (RCC) makes up 2-3\% of adult cancers. The introduction of tyrosine kinase inhibitors (TKIs) and mammalian target of rapamycin inhibitors in the mid-2000s radically changed the management of RCC. These targeted treatments superseded immunotherapy with interleukin-2 and interferon. The pendulum now appears to be shifting back towards immunotherapy, with the evidence of prolonged overall survival of patients with metastatic RCC on treatment with the antiprogrammed cell death 1 ligand monoclonal antibody, nivolumab. Clinical prognostic criteria aid prediction of relapse risk for resected localised disease. Unfortunately, for patients at high risk of relapse, no adjuvant treatment has yet shown benefit, although further trials are yet to report. Clinical prognostic models also have a role in the management of advanced disease; now there is a pressing need for predictive biomarkers to direct therapy. Treatment selection for metastatic disease is currently based on histology, prognostic group and patient preference based on side effect profile. In this article, we review the current medical and surgical management of localised, oligometastatic and advanced RCC, including side effect management and the evidence base for management of poor-risk and non-clear cell disease. We discuss recent results from clinical trials and how these are likely to shape future practice and a renaissance of immunotherapy for renal cell cancer.

Renal cell carcinoma (RCC) represents $2-3 \%$ of all adult cancers (Rini et al, 2009a). It is the seventh most common malignancy in men, and the ninth in women (Rini et al, 2009a) with 10144 new cases and 4252 deaths in the United Kingdom per year (Cancer Research UK, 2016). Risk factors include hypertension, smoking, obesity and endstage renal disease. With increasing use of radiological investigations, there has been a steady increase in the rate of incidental diagnosis, which now accounts for half of all new RCC cases. A third of cases present with metastatic disease at diagnosis (Gupta et al, 2008) and a third of those undergoing surgery for early stage disease will relapse, after a median of 1.9 years (Stewart et al, 2014).

The most common subtype of RCC is clear cell RCC (ccRCC; $70-80 \%)$, with papillary (10-15\%) and chromophobe tumours (3$5 \%)$ making up the majority of the remainder (Rini et al, 2009a). Clear cell RCC is characteristically associated with the loss of function of the VHL (von Hippel-Landau) gene, in the majority of tumours, whether by somatic mutation, chromosomal loss or epigenetic silencing (Gossage et al, 2015). The VHL gene is on chromosome 3p25 and is an established two-hit tumour suppressor gene; one allele typically inactivated by mutation or promoter methylation, and the other lost due to a large deletion (Gossage et al, 2014). The loss of functional VHL protein (pVHL) leads to the increased expression of hypoxia inducible factors (HIFs) and the expression of a wide range of genes involved in cancer progression and metastasis including vascular endothelial growth factor (VEGF) (Gossage et al, 2015).

In this review, we discuss the latest advances in the management of local and advanced disease and the rebirth of immunotherapy for RCC.

\section{MANAGEMENT OF EARLY STAGE DISEASE}

The expansion in cross-sectional imaging over the last few decades means that the majority of early stage RCC diagnoses are now the result of incidental findings. This has led to a debate over how to best manage small lesions of unknown significance, particularly in frail, elderly patients in whom the increased competing cause mortality tips the balance towards active surveillance (Hollingsworth et al, 2007). Further work is required in terms of both radiological and serological markers to aid decision-making.

*Correspondence: Dr B Greef; E-mail basma@doctors.org.uk

Received 21 March 2016; revised 6 June 2016; accepted 29 June 2016; published online 4 August 2016 
Table 1. Progression-free survival and overall survival by AJCC stage after surgical resection for localised and locally advanced RCC (Russo et al, 2008)

\begin{tabular}{|l|c|c|c|c|}
\hline AJCC stage & $\begin{array}{c}\mathbf{5 - Y e a r} \\
\text { PFS (\%) }\end{array}$ & $\mathbf{9 5 \%} \mathbf{C l}$ & $\begin{array}{c}\mathbf{5 - Y e a r ~} \\
\text { OS (\%) }\end{array}$ & $\mathbf{9 5 \% ~ C l}$ \\
\hline T1 & 95 & $93-97$ & 87 & $85-90$ \\
\hline T2 & 74 & $64-82$ & 76 & $67-83$ \\
\hline T3 & 81 & $76-85$ & 72 & $67-77$ \\
\hline T4 & 22 & $3-51$ & 22 & $3-51$ \\
\hline $\begin{array}{l}\text { Abbreviations: } \mathrm{Cl}=\text { confidence interval; OS=overall } \\
\text { survival. }\end{array}$ \\
\hline
\end{tabular}

Localised (T1 and T2) RCC is cured by surgery alone in the majority of cases with 5-year progression-free survival (PFS) in patients undergoing surgery for T1 and T2 disease of $95 \%$ and 74\%, respectively (Russo et al, 2008) (Table 1).

Open radical nephrectomy was for four decades the standard of surgical care for RCC (Robson et al, 1969). Partial nephrectomy was initially adopted as a nephron-sparing procedure for selective indications (solitary kidney and poor renal function), but is now standard treatment for organ-confined tumours at the renal poles measuring $<7 \mathrm{~cm}$ (T1 disease) (Escudier et al, 2014c). In patients with locally advanced (T3 and T4 disease), there is no proven role for adrenalectomy or routine lymph node dissection in the absence of radiological evidence of lymph node or adrenal involvement (Escudier et al, 2014c).

Laparoscopic approaches for both partial and radical nephrectomy are now recommended where technically possible for T1 and T2 tumours, with the data to suggest equivalent disease control when compared with open surgery (MacLennan et al, 2012). Robot-assisted nephrectomy was first described in 2000, and is increasingly being adopted. The evidence base for robot-assisted nephrectomy remains limited, with only a single prospective trial comparing laparoscopic and robot-assisted radical nephrectomy for localised disease, with a small sample size $(n=30)$ and followup of less than a year (Hemal and Kumar, 2009). Outcomes in that study and a handful of other retrospective series appear to be equivalent (Asimakopoulos et al, 2014).

Post-operative recurrence rates for patients with locally advanced (T3 and T4) disease are high, but despite this, the utility of adjuvant treatment following has not yet been established. Recent results of a planned interim analysis from the ASSURE study comparing 1 year of adjuvant treatment with either sunitinib or sorafenib $v s$ placebo for patients with intermediate and high-risk resected RCC have disappointingly shown no advantage for disease-free survival or overall survival (OS; Haas and Manola). A number of other adjuvant studies using other tyrosine kinase inhibitors (TKIs) and the mammalian target of rapamycin (mTOR) inhibitor everolimus are due to report within the next 2 years $(\mathrm{Pal}$ and Haas, 2014). Although the results of these studies are awaited, radiological surveillance is the standard of care for patients who have undergone nephrectomy (Pal and Haas, 2014; Stewart et al, 2014).

One challenge cited within these adjuvant studies has been the ability to accuratelypredict patients at high risk of recurrence, to enrich the trial population. Recurrence risk stratification models such as the Leibovich score rely on surgical staging and histopathological features to categorise patients according to recurrence risk (Leibovich et al, 2003; Table 2). Rini et al (2015a) recently developed a 16-gene assay (11 cancer-related and 5 reference genes) to stratify patients who had undergone nephrectomy for localised RCC retrospectively, according to the risk of recurrence. Patterns of gene expression were used to re-classify patients into high, intermediate and low risk of renal cancer recurrence. Interestingly, this led to $15 \%$ of stage 1 patients
Table 2. The Leibovich Score, an algorithm for predicting metastases after radical nephrectomy (Leibovich et al, 2003)

\begin{tabular}{|c|c|c|}
\hline \multicolumn{2}{|l|}{ Feature } & Score \\
\hline \multicolumn{3}{|c|}{ Primary tumour status } \\
\hline \multicolumn{2}{|c|}{ pT1a } & 0 \\
\hline \multicolumn{2}{|l|}{ pT1b } & 2 \\
\hline \multicolumn{2}{|l|}{ pT2 } & 3 \\
\hline \multicolumn{2}{|l|}{ рT3a } & 4 \\
\hline \multicolumn{2}{|l|}{ рT3b } & 4 \\
\hline \multicolumn{2}{|l|}{ pT3c } & 4 \\
\hline \multicolumn{2}{|l|}{ pT4 } & 4 \\
\hline \multicolumn{3}{|c|}{ Regional lymph node status } \\
\hline \multicolumn{2}{|c|}{$\mathrm{pNx}$} & 0 \\
\hline \multicolumn{2}{|l|}{ pNO } & 0 \\
\hline \multicolumn{2}{|l|}{ pN1 } & 2 \\
\hline \multicolumn{2}{|l|}{ pN2 } & 2 \\
\hline \multicolumn{3}{|l|}{ Tumour size $(\mathrm{cm})$} \\
\hline \multirow{2}{*}{\multicolumn{2}{|c|}{$\begin{array}{l}<10 \\
\geqslant 10\end{array}$}} & 0 \\
\hline & & 1 \\
\hline \multicolumn{3}{|l|}{ Nuclear grade } \\
\hline \multicolumn{2}{|l|}{1} & 0 \\
\hline \multicolumn{2}{|l|}{2} & 0 \\
\hline \multicolumn{2}{|l|}{$\begin{array}{l}3 \\
4\end{array}$} & 1 \\
\hline \multicolumn{2}{|l|}{4} & 3 \\
\hline \multicolumn{3}{|c|}{ Histologic tumour necrosis } \\
\hline & 0 \\
\hline \multicolumn{2}{|l|}{ Yes } & 1 \\
\hline Risk group (score) & $\begin{array}{l}\text { 5-Year metastasis- } \\
\text { free survival }\end{array}$ & $\begin{array}{l}\text { 10-Year metastasis- } \\
\text { free survival }\end{array}$ \\
\hline Low $(0,1,2)$ & $97.1 \%$ & $92.5 \%$ \\
\hline Intermediate $(3,4,5)$ & $73.8 \%$ & $64.3 \%$ \\
\hline High $(\geqslant 6)$ & $31.2 \%$ & $23.6 \%$ \\
\hline
\end{tabular}

being re-classified as high risk and conversely $19 \%$ of stage $2-3$ patients being shown to be at low risk of recurrence. The recurrence score improved on the ability of Leibovich score to predict the risk of recurrence. Assessment of expression patterns from multiple sites of single tumours showed consistent gene expression patterns, although this was only performed for eight patients (Rini et al, 2015a). This consistency is in contrast to the work of Gerlinger et al (2012), who found that different biopsy sites led to differing expression patterns. Further prospective clinical evaluation of this approach is warranted. Such a strategy may represent a prognostic biomarker able to enrich recruitment to future adjuvant studies as well as guiding patient stratification in therapeutic trials more widely.

\section{MANAGEMENT OF OLIGOMETASTATIC DISEASE}

Beyond surgery for early stage disease, there is a further role for surgery in the management of oligometastatic disease. Resection of oligometastatic disease can have a range of benefits in selected patients including cure, prolonging survival, palliating symptoms and delaying the need to commence systemic treatment (Kavolius et al, 1998). Again the questions of how to select patients appropriate for surgery, and how to time it can be a nuanced one. There is evidence for improved outcome in patients with a longer disease-free interval, and lung metastases are associated with a better prognosis than those at other sites (Kavolius et al, 1998). Our local approach is to operate on completely resectable metastases that remain stable after a period of 3-6 months' 
observation to exclude the possibility of early development of multiple metastases.

There has been an emerging role for specialist imaging in this field (Gerety et al, 2015) and there remains a need for biomarkers to aid with the detection of occult metastatic disease (Tunuguntla and Jorda, 2008; Gerety et al, 2015). Neither approach is currently in routine clinical use. There is no evidence for the role of adjuvant treatment following metastectomy and standard treatment is to continue regular radiological surveillance of such patients.

\section{MANAGEMENT OF ADVANCED DISEASE}

The discovery of the underlying biology in ccRCC led to the introduction a decade ago of drugs targeting the VEGF and mTOR pathways, which became the standard of therapy for metastatic RCC (mRCC). These targeted drugs, pazopanib, sunitinib, sorafenib, axitinib, bevacizumab, everolimus and temsirolimus transformed the management of mRCC after being shown to be superior to cytokine therapy and placebo in pivotal phase 3 trials (Escudier et al, 2007, 2014a; Hudes et al, 2007; Motzer et al, 2007, 2008, 2013; Rini et al, 2008; Sternberg et al, 2010).

Their widespread adoption ended an era in which cytokine immunotherapy, with interferon- $\alpha$ (IFN- $\alpha)$ or high-dose interleukin-2 (HD Il-2), was the only effective treatment option in mRCC, only suitable for selected patients and with poor overall response rates. Since the exciting period of the introduction of these medications in the mid-2000s, progress plateaued in the management of mRCC. Despite first- and second-line agents, 5year survival remains poor, and complete and durable responses are rare.

\section{CLINICAL PROGNOSTIC MODELS}

Clinical prognostic models are important in treatment planning in mRCC, guiding decisions ranging from whether to undertake a cytoreductive nephrectomy to choice of therapy.

The Memorial Sloan Kettering Comprehensive Cancer Center (MSKCCC) criteria were developed to predict survival in patients with mRCC, using clinical factors including low Karnofsky performance status, anaemia, elevated $\mathrm{LDH}$, hypercalcaemia and absence of prior nephrectomy to divide patients into prognostic groups (Motzer et al, 1999). The model was refined in 2002 to encompass all the risk factors named above, but replacing absence of prior nephrectomy with time from initial RCC diagnosis to commencement of therapy of $<1$ year (Motzer et al, 2002). The MSKCC model was developed during the cytokine era, and was subsequently validated in the TKI population era by Heng et al (2009, 2013) who confirmed four of the five MSKCC criteria (excluding elevated $\mathrm{LDH}$ ) as independent predictors of poor prognosis, and added neutrophilia and thrombocytosis as additional risk factors, with a median survival of 43.2, 22.5 and 7.8 months in the favourable, intermediate and poor prognostic groups, respectively (Table 3 ).

\section{TOWARDS PROGNOSTIC BIOMARKERS IN CCRCC}

Patients with ccRCC demonstrate a wide range of clinical behaviours, from indolent, slowly progressive oligometastatic disease to aggressive, rapidly deteriorating phenotypes. There is also a wide range of response to currently available therapies. There is therefore much to be gained from developing prognostic and predictive biomarkers. Currently, patients are stratified prognostically according to clinical and laboratory parameters ( $\mathrm{Li}$ et al,
Table 3. The International Metastatic Renal-Cell Carcinoma Database Consortium Model for prognosis in first-line treatment for metastatic RCC (Heng et al, 2013)

\section{Criteria}

Karnofsky performance status $<80 \%$

Time from diagnosis to treatments $<1$ year

$\mathrm{Hb}<\mathrm{LLN}$

Corrected calcium $>$ ULN

Neutrophils $>$ ULN

Platelets $>$ ULN

\begin{tabular}{|l|l|c|}
\hline Number of criteria & Group & Median overall survival \\
\hline 0 & Favourable & 43.2 months $(95 \% \mathrm{Cl} 31.4-50.1)$ \\
\hline $1-2$ & Intermediate & 33.5 months $(95 \% \mathrm{Cl} 18.7-25.1)$ \\
\hline $3-6$ & Poor & 7.8 months $(95 \% \mathrm{Cl}$ 6.5-9.7) \\
\hline
\end{tabular}

Abbreviations: LLN = lower limit of normal; ULN = upper limit of normal.

2015), but there remains a huge gap in our knowledge of which genetic and biochemical features within tumours drive the differences. With a high frequency of VHL gene mutation in ccRCC, this gene has made an attractive candidate for a possible biomarker for patient outcome. Despite extensive evaluation there is currently no evidence that the absence or presence of a $V H L$ mutation or the type of mutation has any predictive or prognostic value in sporadic ccRCC (Hakimi et al, 2013; Gossage et al, 2015).

$V H L$ inactivation alone is insufficient for the formation of RCC (Gossage et al, 2015). The genetics of RCC is distinctive in that in addition to mutations in VHL, these tumours have infrequent somatic mutations in known common cancer genes, such as p53 and RAS (Dalgliesh et al, 2010). Three other tumour suppressor genes have been implicated in the development of ccRCC; polybromo 1 (PBRM1; 29-41\%; Varela et al, 2011; Hakimi et al, 2013; Gossage et al, 2014), BRCA1-associated protein 1 (BAP1; 615\%; Peña-Llopis et al, 2012; Hakimi et al, 2013; Gossage et al, 2014) and SET domain containing 2 (SETD2; 3-16\%; Dalgliesh et al, 2010; Duns et al, 2010; Hakimi et al, 2013; Gossage et al, 2014).

Interestingly, all three genes are involved in chromatin function and are located close to $3 \mathrm{p} 21$. The loss of $3 \mathrm{p}$, which is present in $>90 \%$ of ccRCC would knock out one allele of all the three of these tumour suppressor genes (Young et al, 2009). PBRM1 encodes the protein BAF180, which forms part of a chromatin remodelling complex and depleting PBRM1 expression in ccRCC cell lines using small interfering RNA led to the increased cell proliferation (Varela et al, 2011). The BAP1 gene encodes a H2A deubiquitinase, which deubiquitinates histones (Peña-Llopis et al, 2012). SETD2 encodes a H3 lysine methyltransferase, which is involved in the methylation of histones (Dalgliesh et al, 2010). SETD2 knockout is embryonically lethal in mice due to the disruption of embryonic vascular development (Hu et al, 2010).

All the three genes have been investigated as possible prognostic biomarkers in ccRCC. Case series have unanimously found that tumours with $B A P 1$ mutations are associated with more aggressive pathological features and a worse cancer-specific survival (Hakimi et al, 2013). In another retrospective case series, BAP1 mutations were associated with the presence of metastatic disease at presentation and advanced clinical stage, when compared with tumours with PBRM1 mutations (Gossage et al, 2014). In one cohort of 145 patients with ccRCC between 1998 and 2011, median OS was 4.6 years for patients whose tumours harboured BAP1 mutations vs 10.6 years for patients whose tumours harboured PBRM1 mutations (Kapur et al, 2013).

Data regarding the impact of PBRM1 mutations have been inconsistent, with another case series showing that small tumours 
$(<4 \mathrm{~cm})$ with PBRM1 mutations were six times more likely to attain pathological stage pT3a than pT1a (Hakimi et al, 2013). Hakimi et al (2013) found no association between PBRM1 and SETD2, and survival. BAP1 and PBRM1 mutations are almost always mutually exclusive, occurring together at much lower frequencies than would be expected statistically (Pena-LLopis et al, 2013; Joseph et al, 2016), but in case series, results for the minority of patients with both mutations have been inconsistent. One case series found that these patients had a worse outcome with a median OS of 2.1 years, whereas in another case series found no association between $B A P 1$ and PBRM1 mutation status and OS, and also no worsening of prognosis in patients with both mutations (Kapur et al, 2013; Gossage et al, 2014). In a large retrospective cohort of 1400 patients could be divided into four distinct groups clinically based on their BAP1 and PBRM1 mutational status (Joseph et al, 2016). Patients with wild-type $B A P 1$ and PBRM1 had the best 10-year RCC-specific survival, with a stepwise deterioration for patients with $P B R M 1$ loss, followed by those with $B A P 1$ loss. In that case series, patients with the loss of function of both genes had the worst clinical outcome (Joseph et al, 2016).

The mechanism by which these genes responsible for chromatin remodelling may affect the biology of tumours is not understood, but it is interesting to note that in an assessment of tumour heterogeneity in ccRCC by Gerlinger et al (2012) found three different mutations in SETD2 in different metastatic loci, suggesting a role for these mutations as secondary events in the development of an invasive and metastatic phenotype (Gerlinger et al, 2012).

Overall, although a number of genes, including $V H L, P B R M 1$, BAP1 and SETD2 have been investigated as possible prognostic biomarkers, there is at present no validated marker in clinical use.

\section{CYTOREDUCTIVE NEPHRECTOMY}

Cytoreductive nephrectomy was shown to confer an OS advantage in mRCC during the cytokine era, and became an established treatment option but its utility has yet to be proven in the context of TKI treatment (Flanigan et al, 2004). An ongoing prospective study in patients on sunitinib (CARMENA) is expected to report in 2019 (Clinicaltrials.gov, NCT0093033). Questions still remain over the optimum timing for nephrectomy. The SURTIME study is comparing upfront surgery, with surgery after a course of neoadjuvant sunitinib (Clinicaltrials.gov, NCT01099423). Until the results of these trials are available, cytoreductive nephrectomy is offered for palliative reasons for pain or uncontrolled bleeding, or in patients with good performance status with a large primary and small volume metastatic disease (Escudier et al, 2014c).

\section{SYSTEMIC TREATMENT OF ADVANCED RCC}

A decade has passed since cytokine treatment with IFN and HD Il2 were superseded by drugs targeting the VEGF and mTOR pathway based on pivotal phase 3 trials demonstrating their superiority. The anti-VEGF TKIs sorafenib, sunitinib, pazopanib and axitinib (Motzer et al, 2007, 2013; Sternberg et al, 2010; Escudier et al, 2014a), and mTOR inhibitors everolimus and temsirolimus (Hudes et al, 2007; Motzer et al, 2008) have the advantages over cytokine treatment of a higher overall response rate and a more favourable safety profile. Treatments currently available or emerging in $\mathrm{mRCC}$ and their mechanisms of action are summarised in Figure 1.

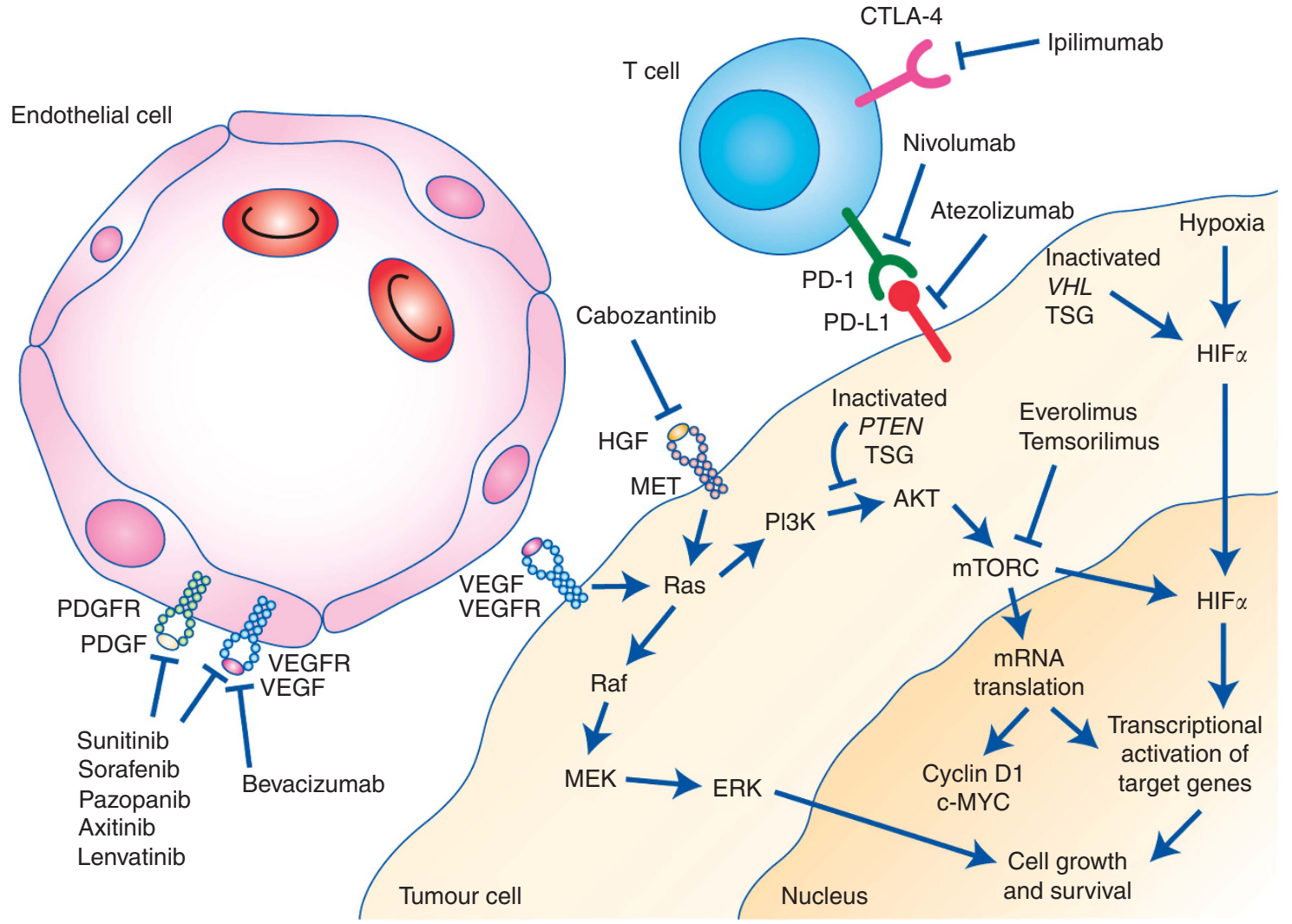

Figure 1. Mechanism of action of treatments for RCC. Abbreviations: CTLA4 = cytotoxic T-lymphocyte-associated antigen 4; HGF = hepatocyte growth factor; PDGF = platelet-derived growth factor; PDGFR = platelet-derived growth factor receptor; PD-1=programmed cell death 1; PDL-1 = programmed cell death ligand 1; VEGF = vascular endothelial growth factor; VEGFR=vascular endothelial growth factor receptor. 


\section{TREATMENT SELECTION IN METASTATIC CCRCC}

As the predominant histological type within RCC, this is the group of patients for which there is the greatest evidence base to guide management. Renal cell carcinoma can sometimes follow an indolent course, therefore a period of observation can be considered before starting treatment (Rini et al, 2014). Immediate treatment is advised however where there is extensive multisite, progressive or symptomatic disease. First-line treatment in mRCC depends heavily on the prognostic category, with differing recommendations for favourable and intermediate-risk disease vs poor-risk disease.

MANAGEMENT OF FAVOURABLE/INTERMEDIATE-RISK CCRCC

First-line treatment. Options for first-line treatment in favourable- and intermediate-risk ccRCC currently include the oral multitargeted kinase inhibitors sunitinib and pazopanib, and the recombinant anti-VEGF monoclonal antibody bevacizumab, in combination with IFN- $\alpha$.

Bevacizumab with IFN- $\alpha$ was approved in the first line in mRCC based on two phase 3 trials, showing that the addition of bevacizumab to IFN- $\alpha$ extended PFS to 8-10 months ( $v s 5$ months; Escudier et al, 2007; Rini et al, 2008), this option is significantly less frequently used compared with the more convenient to administer, oral TKIs. Therefore, the choice in the first-line setting is most commonly between sunitinib and pazopanib.

Sunitinib has demonstrated superiority over IFN- $\alpha$ in a phase 3 trial with a significant improvement in PFS (11 months vs 5 months; Motzer et al, 2007). Pazopanib was approved after being shown to be superior to placebo (9.2 months vs 4.2 months; Sternberg et al, 2010) and subsequently non-inferior to sunitinib in the first-line setting (Motzer et al, 2013). One striking feature of the TKIs is that complete radiological responses are rare, with stable disease being the most frequent best tumour response in the registration trials, occurring in $\sim 39-50 \%$ of patients, with a partial response as the next most common response in 19-31\% (Motzer et al, 2007, 2013; Escudier et al, 2014a).

In view of data showing equivalent efficacy for these two agents, the choice between sunitinib and pazopanib is often based on the differences in their side effect profiles. Sunitinib and pazopanib share a number of side effects in common, including diarrhoea, hypertension, fatigue, nausea and hypothyroidism (Motzer et al, 2013). In the PISCES crossover trial comparing sunitinib with pazopanib, patient preference was in favour of pazopanib $70 \%$ vs $22 \%$, whereas $8 \%$ expressed no preference $(P<0.001$; Escudier et al, 2014b). Fatigue, hand-foot syndrome, stomatitis and myelosupression are commoner with sunitinib treatment, whereas clinically significant LFT derangement and hair colour changes are more associated with pazopanib (Motzer et al, 2013). Pazopanib is associated with higher rates of grade 3 or 4 LFT derangement $(17 \%$ vs $4 \%$ ) and is therefore inadvisable in patients with pre-existing bulky liver disease or baseline LFT derangement (Motzer et al, 2013). Our clinical practice is to counsel patients about both drugs and base decision-making on their lifestyle and the acceptability of the side effect profile of both drugs.

Management of treatment toxicities. The TKIs generally have acceptable side effect profiles, but require careful monitoring and management of side effects, to maintain optimal dosing and drug exposure.

Biochemical evidence of thyroid abnormalities has been reported with all TKIs, but are most common with sunitinib, occurring in up to $70 \%$ of patients, with $15 \%$ requiring treatment
(Wolter et al, 2007; Motzer et al, 2013; Rini et al, 2015c). Patients on all TKIs should have baseline thyroid function tests performed before commencing treatment, and undergo regular surveillance for thyroid abnormalities. Patients who develop overt hypothyroidism (a raised TSH along with a low T4, and/or symptoms of hypothyroidism, or both) require treatment with levothyroxine.

Hypertension is a well-recognised on-target side effect of antiVEGF treatments, occurring in patients receiving TKIs and also the anti-VEGF monoclonal antibody bevacizumab, with a frequency of $17-40 \%$ reported in studies of these drugs (Rini et al, 2015d). It has been proposed that treatment-associated hypertension could be an on-treatment biomarker for response to anti-VEGF treatments (Rini et al, 2011a). Several independent retrospective analyses in patients taking sunitinib for mRCC have confirmed that patients with hypertension have a more favourable response (Rini et al, 2011a; Izzedine et al, 2015). Patients who developed treatmentinduced hypertension (defined by a SBP of $\geqslant 140$ ) had a longer median OS (30.9 months vs 7.2 months) and the overall response rate was also significantly higher in the hypertensive group $(54.8 \%$ vs 8.7\%; Rini et al, 2011a).

There is interesting - albeit retrospective - data that the use of angiotensin system inhibitors (ASI, ACE inhibitors and angiotensin II receptor blockers) is independently associated with an improved response to anti-angiogenic treatment. A large retrospective pooled analysis of 4736 patients receiving treatment for mRCC found that the use of ASI was significantly associated with prolonged OS in patients receiving VEGF-directed therapy, but not in those receiving mTOR inhibitors or IFN (McKay et al, 2015). Median OS was 31 months in the ASI-treated patients vs 20 months in the non-treated patients. It is important to note that this finding is based on retrospective, non-randomised data, and further evaluation in a prospective study is warranted. In the meanwhile, there is reasonable rationale for favouring ASI over other anti-hypertensives in patients on treatment, unless there are reasons to avoid doing so.

Diarrhoea is a class effect of TKIs, with reported frequency of grade 3 and above diarrhoea between 5 and 13\% reported for sunitinib, pazopanib and axitinib (Motzer et al, 2007; Sternberg et al, 2010; Escudier et al, 2014a). Milder diarrhoea is common, occurring in approximately half of patients, and can be managed with oral hydration and the administration of anti-motility agents such as loperamide. There is emerging data to suggest that treatable, reversible causes such as exocrine pancreas insufficiency or bile acid malabsorption may underlie severe diarrhoea in a subgroup of patients on TKIs. Our current clinical practice is to actively screen patients for symptoms such as nocturnal diarrhoea and steattorrhoea, which can be suggestive of these mechanisms (unpublished data). Severe diarrhoea, grade 3 or above warrants withholding treatment until symptoms resolve or return to grade 1 . After this, dose reduction is usually warranted.

The mucositis associated with TKIs is rarely severe enough to warrant treatment interruption or dose reduction. Management is symptomatic with good oral hygiene and dietary modification.

Traditional management of treatment toxicity with TKIs has been to dose reduce, but adopting alternate treatment scheduling may not only increase tolerability but also enhance oncological outcomes. Standard treatment with sunitinib is $50 \mathrm{mg}$ once a day for 4 weeks followed by a 2 -week break. The dose of sunitinib is reduced by increments of $12.5 \mathrm{mg}$ if this dose is not tolerated. A retrospective Canadian series including 172 patients has suggested that a more individualised approach to treatment scheduling may not only improve tolerability but also improve oncological outcomes (Bjarnason et al, 2014). Patients on a range of alternate schedules - including 2 weeks on treatment followed by a 1-week break - had superior OS and PFS compared with those on standard scheduling (Bjarnason et al, 2014). A prospective trial of this individualised approach to scheduling sunitinib is ongoing 
(clinicaltrials.gov, NCT NCT01499121). Once commenced on TKIs, it is standard practice for patients to be treated continuously until progression, although it is not known whether this approach is superior to interrupted treatment. The ongoing STAR trial aims randomises patients with locally advanced or metastatic ccRCC to either continuous or interrupted treatment with either sunitinib or pazopanib, according to physicians' preference and is expected to report in 2020 (Isrctn.com, ISRCTN06473203).

Second-line treatment. Patients who progress on first-line TKI therapy have the option of either a second-line TKI (axitinib) or an mTOR inhibitor, everolimus (Motzer et al, 2008; Rini et al, 2011b). Mammalian target of rapamycin is a serine/threonine kinase that is a downstream effector of the PI3K/AKT pathway. Targeting mTOR is of particular relevance in RCC, because in the majority of cases, the loss of pVHL leads to constitutive activation of the HIFs, resulting in the upregulation of many HIF targets associated with angiogenesis, metabolic adaption and metastasis, including VEGF. Mammalian target of rapamycin has been found to increase HIF at the translational level, therefore inhibition of mTOR can be seen to be particularly useful in RCC (Batelli and Cho, 2011).

Everolimus was approved on the basis of the phase 3 randomised RECORD-1 study, which compared everolimus with placebo for patients with good- or intermediate-risk features (as per MSKCC criteria), who had progressed on sunitinib or sorafenib (Motzer et al, 2008). A quarter of patients included had received prior treatment with multiple TKIs and it was also permitted for patients have had prior treatment with other agents including IFN and interleukin-2. As a result, a large proportion of patients were receiving everolimus in the third-line setting or later. The trial was stopped early after interim results showed a doubling of PFS (4.0 months vs 1.9 months). The FDA approved everolimus on the basis of these results for patients who have progressed on other targeted therapies.

Clinicians often base their choice of second-line therapy between everolimus and axitinib on the response to the first-line TKI. A retrospective series of 464 patients demonstrated no association between the response to first-line TKI and response to second-line TKI (Al-Marrawi et al, 2013). Another retrospective series found that PFS of $\geqslant 12$ months to first-line TKI predicted a better response to second-line treatment, whereas a low albumin, elevated serum $\mathrm{LDH}$ and elevated calcium were all predictors of a poor response (Sacré et al, 2016). A number of biomarkers have undergone evaluation, but there are none currently in clinical practice to guide the choice of which therapeutic modality to use.

Recent trial evidence has led to an interest in the use of MET inhibitors in the second line for ccRCC. $c$-MET is a proto-oncogene on chromosome 7 , which encodes a transmembrane tyrosine kinase, the cell surface receptor for the growth factor hepatocyte growth factor. Activating mutations in $c-M E T$ been identified in hereditary and sporadic papillary RCC (pRCC) (Haas and Nathanson, 2014). More recently, $c-M E T$ has also been shown to be overexpressed in ccRCC, as a result of the loss of pVHL, and is an independent negative prognostic marker (Gibney et al, 2013). Cabozantinib is a small-molecule TKI, currently approved for metastatic medullary thyroid cancer that inhibits VEGF, MET and AXL; each implicated in the pathogenesis of RCC or the development of resistance

Recent results of the phase 3 METEOR study in which the MET inhibitor cabozantinib was compared with everolimus in patients with ccRCC who had progressed after TKI therapy have added to the considerable interest in harnessing this mechanism clinically (Choueiri et al, 2015). Cabozantinib showed a significant PFS advantage with a median PFS of 7.4 months vs 3.8 months for everolimus. The hazard ratio (HR) for progression or death was 0.58 (95\% CI $0.45-075, P<0.001$ ). The interim threshold for significance for OS was not met. This promising result suggests a future role for cabozantinib as part of the ccRCC management paradigm, likely displacing everolimus further down the treatment hierarchy. Activation of the fibroblast growth factor pathway has been suggested as a mechanism of resistance to TKIs. The antiFGFR and anti-VEGF TKI dovitinib showed no advantage in the third line over sorafenib in patients previously treated with both a TKI and mTOR inhibitor (Motzer et al, 2014). There remains a significant unmet need for effective treatments to overcome resistance to therapy.

\section{MANAGEMENT OF POOR-RISK CCRCC}

The use of temsirolimus as first-line treatment in poor-risk mRCC is supported by a phase 3 trial in untreated patients with three out of six predictors of poor outcome (including the five MSKCC criteria, with the addition of metastases in multiple organs; Hudes et al, 2007). Patients were randomised to temsirolimus, temsirolimus plus IFN $-\alpha$ or IFN $-\alpha$ alone. There was a significant improvement in OS with temsirolimus compared with IFN- $\alpha$ or a combination of both drugs. OS was 10.9 months for temsirolimus $v s 7.3$ months for IFN. In a subgroup analysis, the benefit of temsirolimus was limited to patients under the age of 65 (Hudes et al, 2007).

Although European guidelines recommend temsirolimus for first-line treatment in poor-risk patients with $\mathrm{mRCC}$, in practice this treatment - administered as a weekly infusion - is very little used in Europe (Escudier et al, 2014c). The trials that led to the licensing of sunitinib, pazopanib and bevacizumab/IFN all included a small cohort of poor prognosis patients $(<10 \%)$, making these drugs the more usually used first-line treatments, in those patients fit enough to receive them (Escudier et al, 2007; Motzer et al, 2007; Rini et al, 2008; Sternberg et al, 2010).

Axitinib is not currently available in the first line outside of trials, but is currently being evaluated in the single arm A-Predict study, in patients unsuitable for cytoreductive nephrectomy according to physician discretion, and therefore likely to include a significant cohort of poor-risk patients (Clinicaltrials.gov, NCT01693822). Results are expected in the Autumn of 2016.

\section{TREATMENT SELECTION IN NON-CCRCC}

There is increasing recognition that non-clear cell variants of RCC can be subdivided into distinct histological groups, with differing underlying biology and clinical behaviour. Much of our knowledge in this area arises from the study of hereditary RCC, and although we are learning more and more about the molecular mechanisms of these diseases, type-specific therapies are largely yet to be identified.

Patients with non-clear cell histology have been and continue to be excluded from the majority of large therapeutic trials. As such, there is a limited evidence base regarding choice of first and subsequent lines of treatment in metastatic non-ccRCC. A fifth of patients in the registration trial for temsirolimus had non-clear cell histology, and a subgroup analysis showed that benefit of temsirolimus in this group of patients was greater than in patients with clear cell histology (Dutcher et al, 2009). For patients with clear cell histology and non-clear cell histology, the HR for death or progression was with temsirolimus vs IFN were 0.76 (95\% CI $0.6-0.97$ ) and 0.38 (95\% CI $0.23-0.62$ ), respectively (Dutcher et al, 2009).

Further evidence for treatment selection in non-ccRCC comes from recent results of the phase 2 ASPEN trial of everolimus vs sunitinib in the first-line setting (Armstrong et al, 2016). The study included patients with papillary (66\%), chromophobe (15\%) or unclassified (19\%) histology, and allowed patients of any MSKCC risk group. Sunitinib was superior to everolimus overall with a PFS of 8.3 months $v s 5.6$ months. However, an interesting differential effect was seen according to histological subtype and MSKCC risk 
group. The results favoured sunitinib for good- and intermediaterisk disease, and papillary or unclassified histology. However, for MSKCC poor-risk disease or chromophobe histology, everolimus was superior. These results provide some guidance for clinicians selecting first-line treatments in patients with non-clear cell histology, an area of clear unmet need.

Papillary RCC is the second most common histological type after clear cell, accounting for $10-15 \%$ of cases of RCC. Hereditary type 1 pRCC is caused by a germline mutation in the $c-M E T$ protooncogene, and MET mutation or overexpression is commonly found in sporadic pRCC also. There is therefore a good rationale for the use of MET inhibitors in pRCC particularly type 1. Ongoing phase 2 trials are assessing the role of the MET inhibitors savolitinib, cabozantinib and crizotinib in pRCC (NCT02761057 and NCT02127710). Another phase 2 trial is examining the MET inhibitor tivotinib (ARQ197) as a single agent, or in combination with the epidermal growth factor receptor inhibitor erlotinib (NCT01688973). Following the success of cabozatinib in the second-line setting in ccRCC, in which MET has also been found to be important, further study of MET inhibitors in pRCC are clearly needed (Choueiri et al, 2015).

\section{COMBINATION THERAPY}

The only drug combination in current clinical use is bevacizumab with IFN (Escudier et al, 2007; Rini et al, 2008). There is a good rational for attempting dual targeting of both the mTOR and VEGF receptor pathways in mRCC, but until recently results from trials of this approach have been unsuccessful, with several negative results from trials using this approach showing no clear benefit from combining treatments, only an increase in toxicity.

However, recent success of the combination of the TKI lenvatinib with everolimus in the second line has is the first positive result for this strategy. Motzer et al (2015b) combined the novel multitargeted TKI lenvatinib with everolimus, in a phase 2 study in patients with metastatic ccRCC who had progressed on a first-line TKI. Patients were randomised to lenvatinib, everolimus or a combination of both drugs. This trial showed a significant PFS advantage for the combination arm $v s$ single agent everolimus 14.6 months $v s 5.5$ months $(P=0.005)$. Progression-free survival was 7.4 months in the single agent lenvatinib arm, which was significantly longer than for everolimus $(P=0.048)$. Rates of grade 3 or 4 toxicity were similar in the lenvatinib-containing arms and higher than in the everolimus arms (45\% for the combination, $44 \%$ for lenvatinib and $38 \%$ in the everolimus group). The most common toxicities in the combination group were diarrhoea, reduced appetite and fatigue, and were manageable with dose reductions. The significant PFS advantage of the combination arm and its manageable toxicity profile, make lenvatinib-everolimus an attractive treatment option over using these drugs sequentially.

RCC is generally highly resistant to cytoxic chemotherapy, but there is some emerging evidence of efficacy when combined with a TKI in sarcomatoid RCC. Michaelson et al (2015) reported a phase 2 study of the combination of gemcitabine with sunitinib in patients poor-risk features, including patients with sarcomatoid histology the combination was tolerated and showed some activity and is currently being evaluated in a randomised study (Clinicaltrials.gov, NCT01164228).

\section{IMMUNOTHERAPY - TIME FOR A REPRISE}

Spontaneous regressions of both localised and mRCC, although rare are known to occur (Dickerson et al, 2015). Recognition of this phenomenon - presumed to be immune mediated - led to the interest in harnessing the immune system in the treatment of this disease and ushered in an era when immunotherapy with IFN- $\alpha$ and Il-2 was the mainstay of the treatment for mRCC (Raman and Vaena, 2015), until the introduction of TKIs and mTOR inhibitors in the mid-2000s.

Interleukin-2. High-dose interleukin-2 remains a therapeutic option for highly selected groups of patients. Significantly, 70\% of the $10-15 \%$ of patients who show a complete response to Il-2 appear to have been cured after a long-term follow-up (Fyfe et al, 1996). Careful patient selection is highly important for this toxic treatment with significant treatment-related morbidity and mortality. McDermott et al (2015) published the SELECT trial in which selecting patients for IL-2 by clinical features (clear cell, PSO) led to a doubling of the response rate, compared with the historical response rate. Predictors of poor response to Il-2 include papillary histology, $>50 \%$ granular cells or no alveolar features (Shablak et al, 2011).

Cancer vaccines. Cancer vaccines are designed to enhance antitumour immunity, by presenting tumour antigens to $\mathrm{T}$ cells. There are several types of vaccine including autologous tumour cells, peptide-based vaccines and dendritic cell (DC)-based vaccines. The most promising vaccines in RCC have been peptide and DC based.

IMA901 is a peptide-based cancer vaccine, which presents multiple tumour-associated peptides, with the aim of increasing the number of tumour-specific T cells. The results of the phase 3 IMPRINT study were announced at ESMO 2015, with no survival advantage to the addition of IMA901 to sunitinib $v s$ sunitinib alone (Rini et al, 2015b).

Dendritic cells are important antigen-presenting cells for the induction of a T-cell immune response. Originating in the bone marrow they infliltrate peripheral tissues - including tumour tissues - in their immature form. In response to inflammatory signals, DCs migrate to the lymph nodes presenting antigens to $\mathrm{T}$ cells to stimulate an immune response. Dendritic cell-based vaccines are labour-intensive to create, as an individual patient's DCs must be collected and cultured in vitro, primed with antigens and then re-infused into the patient. The phase 3 ADAPT study randomises patients to either sunitinib alone or sunitinib along with AGS-003, an autologous DC-based vaccine (Clinicaltrials.gov, NCT01582672), with results expected in April 2017.

T-cell checkpoint inhibitors. An increase in knowledge of the biology of the immune response to cancer has led to the development of a new class of treatments, the T-cell checkpoint inhibitors (TCCIs; Figure 1). Programmed cell death 1 (PD-1) and cytotoxic T-lymphocyte-associated antigen 4 (CTLA4) are both expressed on the surface of $\mathrm{T}$ cells and activation of these receptors leads to a dampening of the T-cell anti-tumour response. Blockade of these pathways with monoclonal antibodies against CTLA4 (ipilimumab) and PD-1 (nivolumab and pembrolizumab) or its ligand, PDL-1 (atezolizumab), stimulates effector $\mathrm{T}$ cells to enhance their anticancer response. The resulting loss of selftolerance means that the toxicities associated with these drugs are primarily auto-immune in origin. Almost any organ can be affected, although the gastrointestinal, skin, endocrine and pulmonary effects predominate (Pham et al, 2015). The majority of these side effects can be managed by treatment interruption and immunosuppressive therapies when the severity warrants it (Pham et al, 2015). It is vital that clinicians are vigilant for the broad range of toxicities that can arise from these drugs, and the insidious manner in which they can present, as they can, rarely, be fatal. The largest experience of a TCCI (nivolumab) in RCC to date has shown this drug to be relatively well tolerated in this patient population, with a $19 \%$ grade 3 or 4 adverse event rate and no fatalities (Motzer et al, 2015a). 
Clear cell RCC recently has recently joined the growing list of cancers in which the PD-1 immune checkpoint inhibitor nivolumab has been shown to improve OS (Motzer et al, 2015c). The Checkmate025 study compared nivolumab with everolimus in the second-line setting and demonstrated a clear OS advantage for nivolumab (25.0 months $v s 19.6$ months; $P=0.0018)$ at an interim analysis. The HR for death with nivolumab vs everolimus was 0.73 (98.5\% CI, 0.57-0.93, $P=0.002$ ) Complete responses were seen in $1 \%$ of patients on nivolumab, whereas flattening of the KaplanMeier curves suggests enduring responses. Taken together, this is encouraging evidence of rare cures, as well as the possibility of long-term disease control for a minority of patients (Figure 2). This can be contrasted with TKIs that produce short-term clinical benefit in a large proportion of patients but with which sustained and complete responses are rare.

Median PFS was modest and similar in both arms (4.6 months vs 4.4 months; NS), although there was a late separation of the curves. Subgroup analysis showed that these benefits applied to all patients, including those in the poor-risk group, with some suggestion that benefit from nivolumab was in fact greatest in this group. Nivolumab was well tolerated, the rate of grade 3 and 4 adverse events was $19 \%$ vs $35 \%$ for everolimus.

The possibility that nivolumab may be more effective earlier in disease is being explored by the first line, phase 3 CheckMate 214 study, which compares dual blockade of CTLA4 and PD-1 with (nivolumab and ipilimumab) with sunitinib in the first line (Clinicaltrials.gov, NCT02210117). The combination of TCCI with anti-angiogenic monoclonal antibodies is being explored in a number of ongoing studies. Pembrolizumab has been safely combined with bevacizumab in a phase 1 study and a number of other early phase studies are ongoing combining atezolizumab with bevacizumab (Clinicaltrials.gov, NCT01984242), nivolumab with bevacizumab (Clinicaltrials.gov, NCT02210117) and pembrolizumab with aflibercept (NCT00298959; Dudek et al, 2016). Patients with non-clear cell histology were excluded from the Checkmate025 study, but now have access to nivolumab via an expanded access program (ClinicalTrials.gov, NCT02596035).

TKIs remain the first-line treatment for the majority of patients with mRCC, whereas the results of first-line studies are awaited. However, it is likely that within a few years, TCCI will move into the first line. What is unclear at present is the interaction between TKIs and TCCIs, and optimal sequencing and combining of these drugs. There is early evidence from patients who participated in the nivolumab studies, who went on to receive TKIs and mTOR inhibitors that these drugs retain their efficacy post TCCI (Albiges et al, 2015). There is also some suggestion that nivolumab may lead to enduring changes in the tumour microenvironment, which may even enhance future response to further lines of these established therapies.

The modest $25 \%$ objective response rate to nivolumab in the CheckMate025 has significant room for improvement by attempting to combine TCCI with other therapies including other immunotherapies and anti-angiogenics. A number of early phase trials have reported on combinations of TCCI with other agents, and more are ongoing. There is a sound rationale for combining TCCI with TKIs, potentially exploiting some of the immune effects of sunitinib in particular. In RCC, there is a shift from type 1 to a type 2 cytokine immune response, with an accompanying decrease in anti-tumour immunity. Sunitinib treatment has been shown to shift the immune response from type 2 to type 1 (Finke et $a l, 2008$ ) and to decrease myeloid-derived suppressor cells (Ko et al, 2009). The TKI-nivolumab arm of the phase 1 CheckMate016 trial has reported outcomes for the combination of nivolumab with either sunitinib or pazopanib (Amin et al, 2014). Although the nivolumab-sunitinib combination was well tolerated, the pazopanib arm was closed due to dose-limiting toxicities mostly related to hepatotoxicity (Amin et al, 2014). Other early phase studies combining TKIs with TCCI are ongoing including pembrolizumab-pazopanib (NCT02014636), pembrolizumab-axitinib (NCT02133742) and pembrolizumab-lenvatinib (NCT02501096). Another anti-PD-1 monoclonal antibody pidilizumab (CT-011) is being studied in combination with a DC vaccine (clinicaltrials.gov, NCT01441765). The nivolumab-ipilimumab arm of CheckMate016 has also reported results (Hammers et al, 2015). As expected, due to their overlapping toxicities, full doses of nivolumab and ipilimumab (both at $3 \mathrm{mg} \mathrm{kg}^{-1}$ ) were not tolerated. However, nivolumab $3 \mathrm{mg} \mathrm{kg}^{-1}$ with reduced dose ipilimumab at $1 \mathrm{mg} \mathrm{kg}^{-1}$ every 3 weeks, followed by nivolumab at $3 \mathrm{mg} \mathrm{kg}^{-1}$ until progression was reasonably well tolerated - with a $34 \%$ rate of grade three

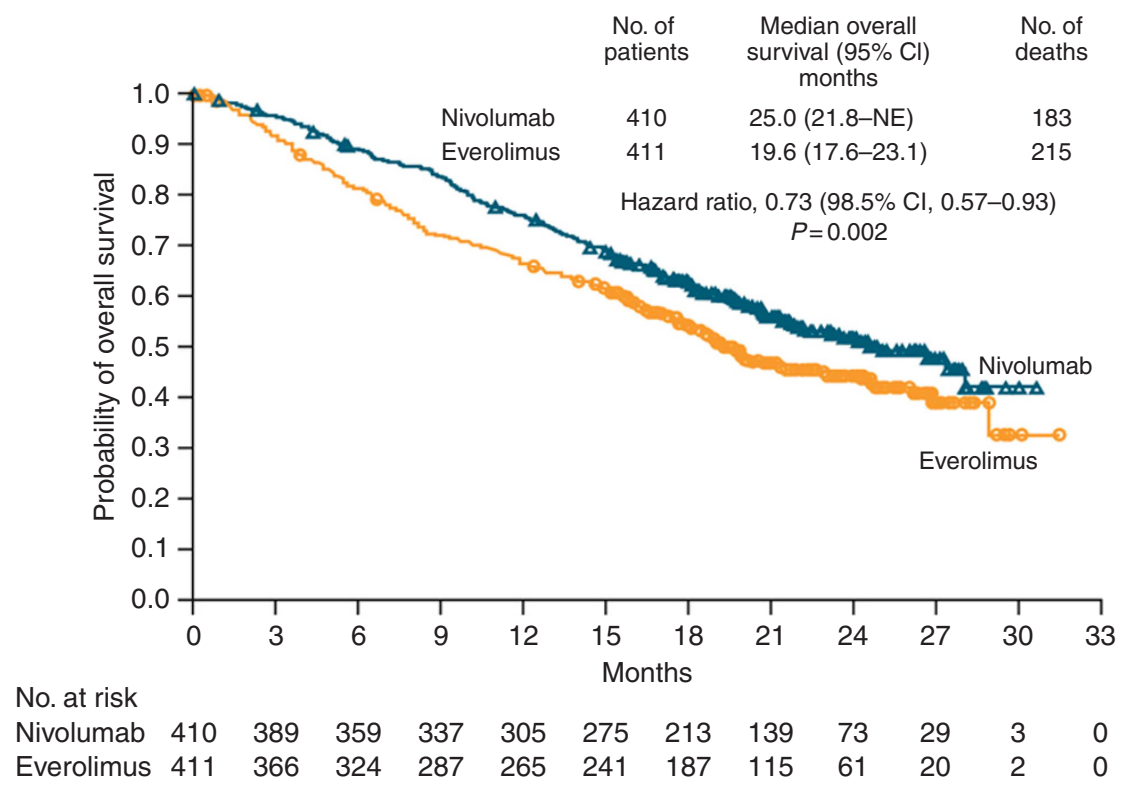

Figure 2. Kaplan-Meier curve for overall survival in the Checkmate025 study (Reproduced with permission from Motzer et al (2015a)). Abbreviations: $\mathrm{Cl}=$ confidence interval; $\mathrm{NE}=$ not estimable. 
adverse events, mostly GI and hepatic. Further evaluation is warranted to determine whether this combination in RCC replicates the improvement in PFS seen in metastatic melanoma (Larkin et al, 2015).

A natural development of the success in mRCC has also been to trial Nivolumab pre- and post cytoreductive nephrectomy in the ongoing ADAPTeR study (Clinicaltrials.gov, NCT02446860) and as a neoadjuvant treatment in localised RCC (Clinicaltrials.gov, NCT02575222).

It has been postulated that high expression levels of programmed cell death 1 ligand (PD-L1) on tumour cell surfaces may be correlated with an enhanced response to nivolumab, as blockade of this pathway restores anti-tumour immunity. Subgroup analysis within the Checkmate025 dividing patients into those with more than or $<1 \%$ PD-L1 expression showed that both groups of patients benefited from nivolumab (Motzer et al, 2015a). A reliable predictive biomarker for selecting patients for nivolumab would be hugely attractive, both to increase efficacy and keep control of the high costs of this drug, which threaten to put them out of the reach of many health systems.

\section{CONCLUSION}

In the mid-2000s, TKIs and mTOR inhibitors transformed the management of mRCC, ending an era in which cytokine-based immunotherapy was available to a minority of patients and outcomes were bleak overall. A decade later, it appears that the success of nivolumab in the Checkpoint025 trial is bringing the management of RCC full circle, with a rebirth for immunotherapy.

The second line in mRCC - once a choice between axitinib and everolimus - is suddenly looking decidedly more crowded. Phase 3 data for cabozantinib and nivolumab support new treatment options for patients, whereas phase 2 data for combination lenvatinib-everolimus encourage the expectation of more options to come. Future studies will need to focus on a head-to-head comparison of these new regimens, although it is likely that with an OS advantage nivolumab will predominate in the second-line setting, with first-line results also eagerly awaited. Complete responses were seen in $1 \%$ of patients on nivolumab and as longerterm follow-up data are awaited, it remains to be seen whether these will translate into long-term cures.

Frustratingly, at this stage, we lack robust predictive biomarkers or the type of 'personalised' medicine seen in some other cancers, and it will surely be crucial for future studies to continue to try to identify those patients most likely to benefit. This has never been more important given the high cost of these emerging drugs and the need to avoid unnecessary toxicities in patients unlikely to benefit.

A number of gaps remain in the management of RCC - effective adjuvant treatment for resected early stage disease, the development of effective predictive and prognostic biomarkers, and curative treatment for advanced disease. The fact remains that despite a decade of established targeted therapy for RCC, the median survival of patients with mRCC is remains under 3 years with systemic therapy. The hope is that a decade from now novel targeted and immunological therapies will have decisively improved the outlook for patients with renal cell cancer.

\section{CONFLICT OF INTEREST}

TE is currently on $80 \%$ leave of absence from the University of Cambridge currently working as VP Oncology Translational Medicine Unit and VP Clinical Discovery Unit, Astrazeneca, Cambridge UK, advisory boards for AVEO, BMS, Bayer, GSK,
Pfizer. Research support from AstraZeneca, Bayer and Pfizer. The remaining authors declare no conflict of interest.

\section{REFERENCES}

Al-Marrawi MY, Rini BI, Harshman LC, Bjarnason G, Wood L, Vaishampayan U, MacKenzie M, Knox JJ, Agarwal N, Al-Harbi H, Kollmannsberger C, Tan M-H, Rha SY, Donskov FN, North S, Choueiri TK, Heng DY (2013) The association of clinical outcome to first-line VEGF-targeted therapy with clinical outcome to second-line VEGFtargeted therapy in metastatic renal cell carcinoma patients. Target Oncol 8: 203-209.

Albiges L, Fay AP, Xie W, Krajewski K, McDermott DF, Heng DYC, Dariane C, DeVelasco G, Lester R, Escudier B, Choueiri TK (2015) Efficacy of targeted therapies after PD-1/PD-L1 blockade in metastatic renal cell carcinoma. Eur J Cancer 51: 2580-2586.

Amin A, Plimack ER, Infante JR, Ernstoff MS, Rini BI, McDermott DF, Knox JJ, Pal SK, Henner Voss M, Sharma P, Kollmannsberger CK, Heng DYC, Spratlin JL, Shen Y, Kurland JF, Gagnier P, Hammers HJ (2014) Nivolumab (anti-PD-1; BMS-936558, ONO-4538) in combination with sunitinib or pazopanib in patients (pts) with metastatic renal cell carcinoma (mRCC). J Clin Oncol 32(5s Suppl): (abstract 5010).

Armstrong AJ, Halabi S, Eisen T, Broderick S, Stadler WM, Jones RJ, Garcia JA, Vaishampayan UN, Picus J, Hawkins RE, Hainsworth JD, Kollmannsberger CK, Logan TF, Puzanov I, Pickering LM, Ryan CW, Protheroe A, Lusk CM, Oberg S, George DJ (2016) Everolimus versus sunitinib for patients with metastatic non-clear cell renal cell carcinoma (ASPEN): a multicentre, open-label, randomised phase 2 trial. Lancet Oncol 17: 378-388.

Asimakopoulos AD, Miano R, Annino F, Micali S, Spera E, Iorio B, Vespasiani G, Gaston R (2014) Robotic radical nephrectomy for renal cell carcinoma: a systematic review. BMC Urol 14: 75.

Batelli C, Cho DC (2011) mTOR inhibitors in renal cell carcinoma. Therapy 8 : 359-367.

Bjarnason GA, Khalil B, Hudson JM, Williams R, Milot LM, Atri M, Kiss A, Burns PN (2014) Outcomes in patients with metastatic renal cell cancer treated with individualized sunitinib therapy: correlation with dynamic microbubble ultrasound data and review of the literature. Urol Oncol 32 : 480-487.

Cancer Research UK (2016) Kidney Cancer Stastistics. Available at http:// www.cancerresearchuk.org/health-professional/cancer-statistics/statisticsby-cancer-type/kidney-cancer (accessed on 05/04/2016).

Choueiri TK, Escudier B, Powles T, Mainwaring PN, Rini BI, Donskov F, Hammers H, Hutson TE, Lee J-L, Peltola K, Roth BJ, Bjarnason GA, Géczi L, Keam B, Maroto P, Heng DYC, Schmidinger M, Kantoff PW, Borgman-Hagey A, Hessel C, Scheffold C, Schwab GM, Tannir NM, Motzer RJ (2015) Cabozantinib versus everolimus in advanced renal-cell carcinoma. N Engl J Med 373: 1814-1823.

Dalgliesh GL, Furge K, Greenman C, Chen L, Bignell G, Butler A, Davies H, Edkins S, Hardy C, Latimer C, Teague J, Andrews J, Barthorpe S, Beare D, Buck G, Campbell PJ, Forbes S, Jia M, Jones D, Knott H, Kok CY, Lau KW, Leroy C, Lin M-L, McBride DJ, Maddison M, Maguire S, McLay K, Menzies A, Mironenko T, Mulderrig L, Mudie L, O’Meara S, Pleasance E, Rajasingham A, Shepherd R, Smith R, Stebbings L, Stephens P, Tang G, Tarpey PS, Turrell K, Dykema KJ, Khoo SK, Petillo D, Wondergem B, Anema J, Kahnoski RJ, Teh BT, Stratton MR, Futreal PA (2010) Systematic sequencing of renal carcinoma reveals inactivation of histone modifying genes. Nature 463: 360-363.

Dickerson EC, Davenport MS, Liu PS (2015) Spontaneous regression of primary renal cell carcinoma following image-guided percutaneous biopsy. Clin Imaging 39: 520-524.

Dudek A, Sica R, Sidani A, Gopalji Jha G, Xie H, Shivaram Alva A, Stein M, Singer E (2016) Phase Ib study of pembrolizumab in combination with bevacizumab for the treatment of metastatic renal cell carcinoma: Big Ten Cancer Research Consortium BTCRC-GU14-003. J Clin Oncol 34(2s Suppl): (abstract 559).

Duns G, van den Berg E, van Duivenbode I, Osinga J, Hollema H, Hofstra RM, Kok K (2010) Histone Methyltransferase Gene SETD2 is a Novel Tumor Suppressor Gene in Clear Cell Renal Cell Carcinoma. Cancer Res 70: 4287-4291.

Dutcher JP, de Souza P, McDermott D, Figlin RA, Berkenblit A, Thiele A, Krygowski M, Strahs A, Feingold J, Hudes G (2009) Effect of temsirolimus 
versus interferon-alpha on outcome of patients with advanced renal cell carcinoma of different tumor histologies. Med Oncol 26: 202-209.

Escudier B, Michaelson MD, Motzer RJ, Hutson TE, Clark JI, Lim HY, Porfiri E, Zalewski P, Kannourakis G, Staehler M, Tarazi J, Rosbrook B, Cisar L, Hariharan S, Kim S, Rini BI (2014a) Axitinib versus sorafenib in advanced renal cell carcinoma: subanalyses by prior therapy from a randomised phase III trial. Br J Cancer 110: 2821-2828.

Escudier B, Pluzanska A, Koralewski P, Ravaud A, Bracarda S, Szczylik C, Chevreau C, Filipek M, Melichar B, Bajetta E, Gorbunova V, Bay JO, Bodrogi I, Jagiello-Gruszfeld A, Moore N (2007) Bevacizumab plus interferon alfa-2a for treatment of metastatic renal cell carcinoma: a randomised, double-blind phase III trial. Lancet 370: 2103-2111.

Escudier B, Porta C, Bono P, Powles T, Eisen T, Sternberg CN, Gschwend JE, De Giorgi U, Parikh O, Hawkins R, Sevin E, Négrier S, Khan S, Diaz J, Redhu S, Mehmud F, Cella D (2014b) Randomized, controlled, double-blind, cross-over trial assessing treatment preference for pazopanib versus sunitinib in patients with metastatic renal cell carcinoma: PISCES Study. J Clin Oncol 32: 1412-1418.

Escudier B, Porta C, Schmidinger M, Algaba F, Patard JJ, Khoo V, Eisen T, Horwich A (2014c) Renal cell carcinoma: ESMO Clinical Practice Guidelines for diagnosis, treatment and follow-up. Ann Oncol 25(S3): iii49-iii56.

Finke JH, Rini B, Ireland J, Rayman P, Richmond A, Golshayan A, Wood L, Elson P, Garcia J, Dreicer R, Bukowski R (2008) Sunitinib reverses type-1 immune suppression and decreases T-regulatory cells in renal cell carcinoma patients. Clin Cancer Res 14: 6674-6682.

Flanigan RC, Mickisch G, Sylvester R, Tangen C, Van Poppel H, Crawford ED (2004) Cytoreductive nephrectomy in patients with metastatic renal cancer: a combined analysis. J Urol 171: 1071-1076.

Fyfe GA, Risher RI, Rosenberg SA, Sznol M, Parkinson DR (1996) Long-term response data for 255 patients with metastatic renal cell carcinoma treated with high-dose recombinant interleukin-2 therapy. J Clin Oncol 14: 2410-2411.

Gerety EL, Lawrence EM, Wason J, Yan H, Hilborne S, Buscombe J, Cheow HK, Shaw AS, Bird N, Fife K, Heard S, Lomas DJ, Matakidou A, Soloviev D, Eisen T, Gallagher FA (2015) Prospective study evaluating the relative sensitivity of $18 \mathrm{~F}-\mathrm{NaF}$ PET/CT for detecting skeletal metastases from renal cell carcinoma in comparison to multidetector CT and 99m Tc-MDP bone scintigraphy, using an adaptive trial design. Ann Oncol 26: 2113-2118.

Gerlinger M, Rowan AJ, Horswell S, Larkin J, Endesfelder D, Gronroos E, Martinez P, Matthews N, Stewart A, Tarpey P, Varela I, Phillimore B, Begum S, McDonald NQ, Butler A, Jones D, Raine K, Latimer C, Santos CR, Nohadani M, Eklund AC, Spencer-Dene B, Clark G, Pickering L, Stamp G, Gore M, Szallasi Z, Downward J, Futreal PA, Swanton C (2012) Intratumor heterogeneity and branched evolution revealed by multiregion sequencing. $N$ Engl J Med 366: 883-892.

Gibney GT, Aziz S a., Camp RL, Conrad P, Schwartz BE, Chen CR, Kelly WK, Kluger HM (2013) C-Met is a prognostic marker and potential therapeutic target in clear cell renal cell carcinoma. Ann Oncol 24: 343-349.

Gossage L, Eisen T, Maher ER (2015) VHL, the story of a tumour suppressor gene. Nat Rev Cancer 15: 55-64.

Gossage L, Murtaza M, Slatter AF, Lichtenstein CP, Warren A, Haynes B, Marass F, Roberts I, Shanahan SJ, Claas A, Dunham A, May AP, Rosenfeld N, Forshew T, Eisen T (2014) Clinical and pathological impact of VHL, PBRM1, BAP1 SETD2, KDM6A and JARIDIc cell renal cell carcinoma. Genes Chromosomes Cancer 53: 38-51.

Gupta K, Miller JD, Li JZ, Russell MW, Charbonneau C (2008) Epidemiologic and socioeconomic burden of metastatic renal cell carcinoma (mRCC): a literature review. Cancer Treat Rev 34: 193-205.

Haas NB, Manola J, Uzzo RG, Atkins MB, Wilding G, Pins M, Jewett MAS, Kane CJ, Cella D, Wagner LI, Coomes B, Wood CG, Dutcher JP, Flaherty K, DiPaola RS (2015) Initial results from ASSURE (E2805): adjuvant sorafenib or sunitinib for unfavourable renal carcinoma, an ECOG-ACRIN-led, NCTN phase III trial. J Clin Oncol 33(Suppl 7): (abstract 403).

Haas NB, Nathanson KL (2014) Hereditary kidney cancer syndromes. Adv Chronic Kidney Dis 21: 81-90.

Hakimi AA, Chen Y-B, Wren J, Gonen M, Abdel-Wahab O, Heguy A, Liu H, Takeda S, Tickoo SK, Reuter VE, Voss MH, Motzer RJ, Coleman JA, Cheng EH, Russo P, Hsieh JJ (2013) Clinical and pathologic impact of select chromatin-modulating tumor suppressors in clear cell renal cell carcinoma. Eur Urol 63: 848-854.
Hammers HJ, Plimack ER, Infante JR, Rini BI, McDermott DF, Ernstoff MS, Henner Voss M, Sharma P, Kumar Pal S, Razak AR, Kollmannsberger CK, Heng DYC, Spratlin JL, Shen Y, Gagnier P, Amin A (2015) Expanded cohort results from CheckMate016: a phase I study of nivolumab in combination with ipilimumab in metastatic renal cell carcinoma (mRCC). J Clin Oncol 33(Suppl): (abstract 4516).

Hemal AK, Kumar A (2009) A prospective comparison of laparoscopic and robotic radical nephrectomy for T1-2N0M0 renal cell carcinoma. World J Urol 27: 89-94.

Heng DY, Xie W, Regan MM, Warren MA, Golshayan AR, Sahi C, Eigl BJ, Ruether JD, Cheng T, North S, Venner P, Knox JJ, Chi KN, Kollmannsberger C, McDermott DF, Oh WK, Atkins MB, Bukowski RM, Rini BI, Choueiri TK (2009) Prognostic factors for overall survival in patients with metastatic renal cell carcinoma treated with vascular endothelial growth factor-targeted agents: results from a large, multicenter study. J Clin Oncol 27: 5794-5799.

Heng DYC, Xie W, Regan MM, Harshman LC, Bjarnason GA, Vaishampayan UN, Mackenzie M, Wood L, Donskov F, Tan MH, Rha SY, Agarwal N, Kollmannsberger C, Rini BI, Choueiri TK (2013) External validation and comparison with other models of the International Metastatic Renal-Cell Carcinoma Database Consortium prognostic model: A population-based study. Lancet Oncol 14: 141-148.

Hollingsworth JM, Miller DC, Daignault S, Hollenbeck BK (2007) Five-year survival after surgical treatment for kidney cancer: A population-based competing risk analysis. Cancer 109: 1763-1768.

Hu M, Sun X-J, Zhang Y-L, Kuang Y, Hu C-Q, Wu W-L, Shen S-H, Du T-T, Li H, He F, Xiao H-S, Wang Z-G, Liu T-X, Lu H, Huang Q-H, Chen S-J, Chen Z (2010) Histone H3 lysine 36 methyltransferase Hypb/Setd2 is required for embryonic vascular remodeling. Proc Natl Acad Sci USA 107: 2956-2961.

Hudes G, Carducci M, Tomczak P, Dutcher J, Figlin R, Kapoor A, Staroslawska E, Sosman J, Mcdermott D, Bodrogi I, Kovacevic Z, Lesovoy V, Schmidt-Wolf IGH, Barbarash O, Gokmen E, Toole TO, Lustgarten S, Moore L, Motzer RJ (2007) Temsirolimus, Interferon Alfa, or Both for Advanced Renal-Cell Carcinoma. N Engl J Med 356: 2271-2281.

Izzedine H, Derosa L, Le Teuff G, Albiges L, Escudier B (2015) Hypertension and angiotensin system inhibitors: impact on outcome in sunitinib-treated patients for metastatic renal cell carcinoma. Ann Oncol 26: 1128-1133.

Joseph RW, Kapur P, Serie DJ, Parasramka M, Ho TH, Cheville JC, Frenkel E, Parker AS, Brugarolas J (2016) Clear cell renal cell carcinoma subtypes identified by BAP1 and PBRM1 expression. J Urol 195: 180-187.

Kapur P, Peña-Llopis S, Christie A, Zhrebker L, Pavía-Jiménez A, Rathmell WK, Xie XJ, Brugarolas J (2013) Effects on survival of BAP1 and PBRM1 mutations in sporadic clear-cell renal-cell carcinoma: a retrospective analysis with independent validation. Lancet Oncol 14: 159-167.

Kavolius JP, Mastorakos DP, Pavlovich C, Russo P, Burt ME, Brady MS (1998) Resection of metastatic renal cell carcinoma. J Clin Oncol 16: 2261-2266.

Ko JS, Zea AH, Rini BI, Ireland JL, Elson P, Cohen P, Golshayan A, Rayman PA, Wood L, Garcia J, Dreicer R, Bukowski R, Finke JH (2009) Sunitinib mediates reversal of myeloid-derived suppressor cell accumulation in renal cell carcinoma patients. Clin Cancer Res 15: 2148-2157.

Larkin J, Chiarion-Sileni V, Gonzalez R, Grob J, Cowey C, Lao C, Schadendorf D, Dummer R, Smylie M, Rutkowski P, Ferrucci PF, Hill A, Wagstaff J, Carlino MS, Haanen JB, Maio M, Marquez-Rodas I, McArthur G, Ascierto P, Long G, Callahan M, Postow M, Grossman K, Sznol M, Dreno B, Bastholt L, Yang A, Rollin L, Horak C, Hodi F, Wolchok J (2015) Combined nivolumab and ipilimumab or monotherapy in untreated melanoma. $N$ Engl J Med 373: 23-34.

Leibovich BC, Blute ML, Cheville JC, Lohse CM, Frank I, Kwon ED, Weaver AL, Parker AS, Zincke H (2003) Prediction of progression after radical nephrectomy for patients with clear cell renal cell carcinoma: a stratification tool for prospective clinical trials. Cancer 97: 1663-1671.

Li H, Samawi H, Heng DYC (2015) The use of prognostic factors in metastatic renal cell carcinoma. Urol Oncol 33: 509-516.

MacLennan S, Imamura M, Lapitan MC, Omar MI, Lam TBL, Hilvano-Cabungcal AM, Royle P, Stewart F, MacLennan G, MacLennan SJ, Canfield SE, McClinton S, Griffiths TRL, Ljungberg B, N’Dow J (2012) Systematic review of oncological outcomes following surgical management of localised renal cancer. Eur Urol 61: 972-993.

McDermott DF, Cheng SC, Signoretti S, Margolin KA, Clark JI, Sosman JA, Dutcher JP, Logan TF, Curti BD, Ernstoff MS, Appleman L, Wong MKK, 
Khushalani NI, Oleksowicz L, Vaishampayan UN, Mier JW, Panka DJ, Bhatt RS, Bailey AS, Leibovich BC, Kwon ED, Kabbinavar FF, Belldegrun AS, Figlin RA, Pantuck AJ, Regan MM, Atkins MB (2015) The High-dose aldesleukin 'select' trial: a trial to prospectively validate predictive models of response to treatment in patients with metastatic renal cell carcinoma. Clin Cancer Res 21: 561-568.

McKay RR, Rodriguez GE, Lin X, Kaymakcalan MD, Hamnvik O-PR, Sabbisetti VS, Bhatt RS, Simantov R, Choueiri TK (2015) Angiotensin system inhibitors and survival outcomes in patients with metastatic renal cell carcinoma. Clin Cancer Res 21: 2471-2479.

Michaelson MD, McKay RR, Werner L, Atkins MB, Van Allen EM, Olivier KM, Song J, Signoretti S, McDermott DF, Choueiri TK (2015) Phase 2 trial of sunitinib and gemcitabine in patients with sarcomatoid and/or poorrisk metastatic renal cell carcinoma. Cancer 121: 3435-3443.

Motzer BRJ, Bacik J, Murphy B a, Russo P, Mazumdar M (2002) Interferon-Alfa as a Comparative Treatment for Clinical. J Clin Oncol 20 289-296.

Motzer RJ, Escudier B, McDermott DF, George S, Hammers HJ, Srinivas S, Tykodi SS, Sosman JA, Procopio G, Plimack ER, Castellano D, Choueiri TK, Gurney H, Donskov F, Bono P, Wagstaff J, Gauler TC, Ueda T, Tomita Y, Schutz FA, Kollmannsberger C, Larkin J, Ravaud A, Simon JS, Xu L-A, Waxman IM, Sharma P. CheckMate 025 Investigators (2015a) Nivolumab versus everolimus in advanced renal-cell carcinoma. N Engl J Med 373: 1803-1813.

Motzer RJ, Escudier B, Oudard S, Hutson TE, Porta C, Bracarda S, Grünwald V, Thompson JA, Figlin RA, Hollaender N, Urbanowitz G, Berg WJ, Kay A, Lebwohl D, Ravaud A (2008) Efficacy of everolimus in advanced renal cell carcinoma: a double-blind, randomised, placebocontrolled phase III trial. Lancet 372: 449-456.

Motzer RJ, Hutson TE, Cella D, Reeves J, Hawkins R, Guo J, Nathan P, Staehler M, de Souza P, Merchan JR, Boleti E, Fife K, Jin J, Jones R, Uemura H, De Giorgi U, Harmenberg U, Wang J, Sternberg CN, Deen K, McCann L, Hackshaw MD, Crescenzo R, Pandite LN, Choueiri TK (2013) Pazopanib versus sunitinib in metastatic renal-cell carcinoma. $N$ Engl J Med 369: 722-731.

Motzer RJ, Hutson TE, Glen H, Michaelson MD, Molina A, Eisen T, Jassem J, Zolnierek J, Maroto JP, Mellado B, Melichar B, Tomasek J, Kremer A, Kim H-J, Wood K, Dutcus C, Larkin J (2015b) Lenvatinib, everolimus, and the combination in patients with metastatic renal cell carcinoma: a randomised, phase 2, open-label, multicentre trial. Lancet Oncol 16: 1473-1482.

Motzer RJ, Hutson TE, Tomczak P, Michaelson MD, Bukowski RM, Rixe O, Oudard S, Negrier S, Szczylik C, Kim ST, Chen I, Bycott PW, Baum CM, Figlin RA (2007) Sunitinib versus interferon alfa in metastatic renal-cell carcinoma. N Engl J Med 356: 115-124.

Motzer RJ, Mazumdar M, Bacik J, Berg W, Amsterdam A, Ferrara J (1999) Survival and prognostic stratification of 670 patients with advanced renal cell carcinoma. J Clin Oncol 17: 2530-2540.

Motzer RJ, Porta C, Vogelzang NJ, Sternberg CN, Szczylik C, Zolnierek J, Kollmannsberger C, Rha SY, Bjarnason GA, Melichar B, De Giorgi U, Grünwald V, Davis ID, Lee J, Esteban E, Sklodowska-curie M (2014) Dovitinib versus sorafenib for third-line targeted treatment of patients with metastatic renal cell carcinoma: an open-label, randomised phase 3 trial. Lancet Oncol 15: 286-296.

Motzer RJ, Rini BI, McDermott DF, Redman BG, Kuzel TM, Harrison MR, Vaishampayan UN, Drabkin HA, George S, Logan TF, Margolin KA, Plimack ER, Lambert AM, Waxman IM, Hammers HJ (2015c) Nivolumab for metastatic renal cell carcinoma: results of a randomized phase ii trial. $J$ Clin Oncol 33: 1430-1437.

Pal SK, Haas NB (2014) Adjuvant therapy for renal cell carcinoma: past, present, and future. Oncologist 19: 851-859.

Pena-LLopis S, Christie A, Xie X-J, Brugarolas J (2013) Co-operation and antagonism among cancer genes: the renal cancer paradigm. Cancer Res 73: 4173-4179.

Peña-Llopis S, Vega-Rubín-de-Celis S, Liao A, Leng N, Pavía-Jiménez A, Wang S, Yamasaki T, Zhrebker L, Sivanand S, Spence P, Kinch L, Hambuch T, Jain S, Lotan Y, Margulis V, Sagalowsky AI, Summerour PB, Kabbani W, Wong SWW, Grishin N, Laurent M, Xie X-J, Haudenschild CD, Ross MT, Bentley DR, Kapur P, Brugarolas J (2012) BAP1 loss defines a new class of renal cell carcinoma. Nat Genet 44: 751-759.
Pham A, Ye D-W, Pal S (2015) Overview and management of toxicities associated with systemic therapies for advanced renal cell carcinoma. Urol Oncol 33: 517-527.

Raman R, Vaena D (2015) Immunotherapy in metastatic renal cell carcinoma: a comprehensive review. Biomed Res Int 2015: 367354.

Rini B, Goddard A, Knezevic D, Maddala T, Zhou M, Aydin H, Campbell S, Elson P, Koscielny S, Lopatin M, Svedman C, Martini J-F, Williams JA, Verkarre V, Radulescu C, Neuzillet Y, Hemmerlé I, Timsit MO, Tsiatis AC, Bonham M, Lebret T, Mejean A, Escudier B (2015a) A 16-gene assay to predict recurrence after surgery in localised renal cell carcinoma: development and validation studies. Lancet Oncol 16: 676-685.

Rini B, Stenzl A, Zdrojowy R, Kogan M, Shkolnik M, Oudard S, Weikert S, Bracarda S, Crabb S, Bedke J, Ludwig J, Maurer D, Mendrzyk R, Mahr A, Fritsch J, Weinschenk T, Singh H, Kirner A, Reindhardt C, Eisen T (2015b) Results from an open-label, randomized, controlled Phase 3 study investigating IMA901 multipeptide cancer vaccine in patients receiving sunitinib as first-line therapy for advanced/metastatic RCC. Eur J Cancer 51(Suppl 3): S718 (abstract 17LBA).

Rini BI, Campbell SC, Escudier B (2009a) Renal cell carcinoma. Lancet 373: 1119-1132.

Rini BI, Cohen DP, Lu DR, Chen I, Hariharan S, Gore ME, Figlin R a., Baum MS, Motzer RJ (2011a) Hypertension as a biomarker of efficacy in patients with metastatic renal cell carcinoma treated with sunitinib. J Natl Cancer Inst 103: 763-773.

Rini BI, Dorff TB, Elson P, Suarez C, Humbert J, Pyle L, Larkin J, Plimack ER (2014) A prospective observational study of metastatic renal cell carcinoma (mRCC) prior to initiation of systemic therapy. J Clin Oncol 32(5s Suppl): (abstract 4520).

Rini BI, Escudier B, Hariharan S, Roberts WG, Tarazi J, Rosbrook B, Askerova Z, DeAnnuntis LL, Motzer RJ (2015c) Long-term safety with axitinib in previously treated patients with metastatic renal cell carcinoma. Clin Genitourin Cancer 13: 540-547.

Rini BI, Escudier B, Tomczak P, Kaprin A, Szczylik C, Hutson TE, Michaelson MD, Gorbunova VA, Gore ME, Rusakov IG, Negrier S, Ou Y-C, Castellano D, Lim HY, Uemura H, Tarazi J, Cella D, Chen C, Rosbrook B, Kim S, Motzer RJ (2011b) Comparative effectiveness of axitinib versus sorafenib in advanced renal cell carcinoma (AXIS): a randomised phase 3 trial. Lancet 378: 1931-1939.

Rini BI, Halabi S, Rosenberg JE, Stadler WM, Vaena DA, Ou S-S, Archer L, Atkins JN, Picus J, Czaykowski P, Dutcher J, Small EJ (2008) Bevacizumab plus interferon alfa compared with interferon alfa monotherapy in patients with metastatic renal cell carcinoma: CALGB 90206. J Clin Oncol 26: 5422-5428.

Rini BI, Quinn DI, Baum M, Wood LS, Tarazi J, Rosbrook B, Arruda LS, Cisar L, Roberts WG, Kim S, Motzer RJ (2015d) Hypertension among patients with renal cell carcinoma receiving axitinib or sorafenib: analysis from the randomized phase III AXIS trial. Target Oncol 10: 45-53.

Robson CJ, Churchill BM, Anderson W (1969) The results of radical nephrectomy for renal cell carcinoma. J Urol 101: 297-301.

Russo P, Jang TL, Pettus JA, Huang WC, Eggener SE, O’Brien MF, Karellas ME, Karanikolas NT, Kagiwada MA (2008) Survival rates after resection for localized kidney cancer: 1989 to 2004. Cancer 113: $84-96$.

Sacré A, Barthélémy P, Korenbaum C, Burgy M, Wolter P, Dumez H, Lerut E, Loyson T, Joniau S, Oyen R, Debruyne PR, Schöffski P, Beuselinck B, Sacré A, Barthélémy P, Korenbaum C, Burgy M, Wolter P, Dumez H, Lerut E, Loyson T, Joniau S, Oyen R, Debruyne PR, Schöffski P, Beuselinck B, Korenbaum C, Burgy M, Wolter P, Dumez H, Sacre A (2016) Prognostic factors in second-line targeted therapy for metastatic clear-cell renal cell carcinoma after progression on an anti-vascular endothelial growth factor receptor tyrosine kinase inhibitor receptor tyrosine kinase inhibitor. Acta Oncol. 55(3): 329-340.

Shablak A, Sikand K, Shanks JH, Thistlethwaite F, Spencer-Shaw A, Hawkins RE (2011) High-dose interleukin-2 can produce a high rate of response and durable remissions in appropriately selected patients with metastatic renal cancer. J Immunother 34: 107-112.

Sternberg CN, Davis ID, Mardiak J, Szczylik C, Lee E, Wagstaff J, Barrios CH, Salman P, Gladkov OA, Kavina A, Zarba JJ, Chen M, McCann L, Pandite L, Roychowdhury DF, Hawkins RE (2010) Pazopanib in locally advanced or metastatic renal cell carcinoma: results of a randomized phase III trial. J Clin Oncol 28: 1061-1068. 
Stewart SB, Thompson RH, Psutka SP, Cheville JC, Lohse CM, Boorjian SA, Leibovich BC (2014) Evaluation of the National Comprehensive Cancer Network and American Urological Association renal cell carcinoma surveillance guidelines. J Clin Oncol 32: 4059-4065.

Tunuguntla HSGR, Jorda M (2008) Diagnostic and prognostic molecular markers in renal cell carcinoma. J Urol 179: 2096-2102.

Varela I, Tarpey P, Raine K, Huang D, Ong CK, Stephens P, Davies H, Jones D, Lin M-L, Teague J, Bignell G, Butler A, Cho J, Dalgliesh GL, Galappaththige D, Greenman C, Hardy C, Jia M, Latimer C, Lau KW, Marshall J, McLaren S, Menzies A, Mudie L, Stebbings L, Largaespada DA, Wessels LFA, Richard S, Kahnoski RJ, Anema J, Tuveson DA, Perez-Mancera PA, Mustonen V, Fischer A, Adams DJ, Rust A, Chan-on W, Subimerb C, Dykema K, Furge K, Campbell PJ, Teh BT, Stratton MR, Futreal PA (2011) Exome sequencing identifies frequent mutation of the SWI/SNF complex gene PBRM1 in renal carcinoma. Nature 469: 539-542.

Wolter P, Dumez H, Schoffski P (2007) Suntinib and Hypothyroidism. N Engl J Med 356: 1580.

Young AC, Craven RA, Cohen D, Taylor C, Booth C, Harnden P, Cairns DA, Astuti D, Gregory W, Maher ER, Knowles MA, Joyce A, Selby PJ,

Banks RE (2009) Analysis of VHL gene alterations and their relationship to clinical parameters in sporadic conventional renal cell carcinoma. Clin Cancer Res 15: 7582-7592.

(c) (1)(2) This work is licensed under the Creative Commons Attribution-Non-Commercial-Share Alike 4.0 International License. To view a copy of this license, visit http:// creativecommons.org/licenses/by-nc-sa/4.0/ 